Indian government not to come to India in any professional capacity - although he is still allowed into the country as a tourist. Taylor ran a nutrition project at Narangwal in the Punjab for some 15 years from 1960 . This project, also funded by the United States, was closed down following allegations that it had been spying on the nearby major Indian airbase at Halwara. Taylor, who was recently passing through Delhi, denies any such charges.

After the closure of the WHO unit in New Delhi and the projects run by Johns Hopkins University, the Indian government has become more strict in the scrutiny of all projects involving foreign collaboration. A central agency that includes the defence adviser has been set up to give foreign-aided projects security clearance. For the past three years the United States has been trying to mount an earthquake project in Shillong and a sedimentology project in the Bay of Bengal. But both projects have been turned down - Shillong is in the politically troubled north-east region while India is sensitive about allowing geological studies in the Bay of Bengal with its huge oil potential.

K.S. Jayaraman

\section{Space communications}

\section{UK jumps in}

Britain is to have a fully-operational direct broadcasting satellite by 1986 , the earliest date foreseen in a Home Office report on direct broadcasting by satellite published just under a year ago. The government's approval for the project last week reflects the urgency with which it now views the exploitation of space and information technologies. It hopes that an early start to the project will give British industry the chance to demonstrate its capabilities and to compete in the world telecommunications market.

The satellite's two direct broadcasting channels have been awarded to the British Broadcasting Corporation, largely because its plans for using them are most advanced. It was also announced last week that British Aerospace, GEC-Marconi and British Telecom are to form a joint venture called United Satellites to build the satellite system. The three companies are now consulting with N.M. Rothschild \& Son, the merchant bank, over ways of raising approximately $£ 150$ million venture capital for the project.

The BBC will lease its two channels, while British Telecom may use another for telecommunications. The plan is to go straight into a fully-operational system involving two satellites in orbit (one a spare) and a third waiting on the ground. According to British Aerospace, the satellite will be based on the ECS, a telecommunications satellite built by the European Space Agency for which British Aerospace was the main contractor. Earlier suggestions that the satellite should be based on L-sat, the second generation of European telecommunications satellites, were abandoned partly because L-sat will be unnecessarily sophisticated and too late.

The BBC will finance its operations mainly out of subscriptions for the programmes carried on one of the channels. One channel will carry repeats of programmes already shown on its two conventional TV channels and the other will be a pay-TV channel showing recentlyreleased feature films and the pick of programmes from foreign television.

Viewers will be able to tune into the satellite by means of small domestic dishes. They may also be able to receive programmes relayed by cable from community dishes. Government plans for cable systems are to be announced shortly, although the Home Office refused this week to comment on a report in last week's Economist that the government is urgently considering plans to lay optical fibres between major cities and coaxial cable between households.

Nevertheless, last week's announcements are evidence of the British government's anxiety that Britain should catch up with other industrialized nations, especially France and Germany, which have been quicker to acknowledge the challenge of space and information technologies. Other moves to exploit some of the lessons Britain has already learnt in space technology, for example through its membership of the European Space Agency, may be expected within a year or so. Officials at the Department of Industry are working on a plan to increase efforts in maritime communications and on a national earth resources programme, part of which would be Britain's contribution to the European Space Agency's proposed Earth Resources Satellite.

Whether these proposals will involve Britain launching its own satellites and just how much public money will be available to fund them, however, remains to be seen.

Judy Redfearn

\section{Information service}

\section{Online Britain}

Pergamon-Infoline, the online scientific and technical information service of the Pergamon/BPC Group, was launched this week by Kenneth Baker, Minister of State for Industry and Information Technology. Infoline will not only be available in the United States but in Britain will represent the first commercial carrier of scientific and technological databases. Although a fledgling from the home nest - its London-based computer - the company wants to break into the markets of Europe and North America and become a "world force in the growing online information industry". A new system, Video PatSearch, is to spearhead its marketing initiative.

For an annual subscription of about
$£ 7,000$ plus online connection charges ( $£ 35$ per hour), Video PatSearch will provide an in-house patent search service. The system, which would sit compactly on a large desk, is the first of its kind to link an online terminal with new video disc technology to enable users to retrieve both drawings from the original patent specification and text. At present the system, which will operate in North America and Europe, is geared to the 750,000 US patents issued scine 1971 .

Hitherto, a subject search of US patents on file at the US Patent Trademark Office has been possible only by using the US Patent Classification System. A search on the computer system may take only 10 to 15 minutes on the average. Video disc technology opens the way to online access to other databases covering subjects where graphics display is necessary.

InfoLine was first set up in 1978 by a consortium including the Department of Industry, the Chemical Society of London, the Institute of Electrical Engineers and the British Library. A long period of development produced only a limited number of databases and in 1980 the partners decided they were unwilling to invest further in the project. The Pergamon Group stepped in and saved InfoLine from liquidation. Several million pounds went into the setting up of an operation based on the advanced VAX $11 / 780$ computer system.

InfoLine complements BLAISE, the online medical retrieval service of the British Library. The databases offered by InfoLine include CA Search, the Chemical Service Databases; Compendex, the engineering database; PIRA Abstracts, covering the paper, publishing, printing and packaging industries; Management and Marketing Abstracts and GeoMechanics Abstracts. All of these databases have been available in the United Kingdom and Europe, via EURONET, for some time. They will now be offered to the US market. PatSearch, the database of US patents, on the US market for two years, will now be offered worldwide from the London computer.

At the opening both Kenneth Baker and Robert Maxwell, chairman of PergamonInfoLine, seemed optimistic that InfoLine would flourish where other governmentbacked schemes had failed. The minister referred to InfoLine as a "tiny bird that escaped the net" (of nationalization).

Jane Wynn

\section{Belgian science policy}

\section{Harsh criticisms}

\section{Brussels}

The parlous state of Belgium's science policy reflects the political and economic problems facing the country. The universities, which shoulder the bulk of statefinanced research, are suffering particularly badly from budgetary cutbacks, and there are loud calls for the government 
to make radical changes in research funding. At the same time, the unequal way in which government-funded research centres are concentrated in the more prosperous Flemish half of the country is the source of bitter complaints from the French-speaking Walloons.

The present escalation of the language war comes in response to the threat of major closures in the steel industry of the already economically depressed Wallonia, and has led Walloons to seek out other injustices to attribute to the present Flemish dominated coalition government.

Belgium has three national research centres, the Centre pour Energie Nucleaire at $\mathrm{Mol}$ in Flanders and the Institut de Radioélements and the Institut National des Industries d'Extraction, both in Wallonia. Eighty-seven per cent of all the government subsidies in question are spent at Mol if the employment created by the nuclear research centre in related industries is taken into account. The last coalition government attempted to redress the balance, at least in terms of energy research, by favouring the coal industry. But this still left 70 per cent of government research funds being spent on nuclear energy compared with 6 per cent on extractive industries. Philippe Maystadt, Science Minister in both the present and previous governments, seems to have done little to soothe Walloon anger since increased expenditure on nuclear energy and solar energy mainly benefits Flanders.

The bad blood between Walloon and Flemish scientists is overshadowed by the crisis facing universities throughout Belgium. A law passed in 1971 lays down that universities are allocated a certain sum of money for each student and out of this the university has to pay for administration, teaching and research. Maystadt ruled out specialist centres for postgraduate research as an unjustifiably expensive way of funding research for a small country.

Research is thus left largely under the control of the university authorities, loosely supervised by a ministerial and an interministerial committee for science policy. In 1981, the universities spent BFr 25,000 million ( $£ 290$ million) compared with $\mathrm{BFr} 15,000$ ( $£ 170$ million) million at other national or international research centres. This has led the universities into a trap with administrative and other running costs rising above the price indexation system and the allocations per student falling below the index increase. The universities have therefore started to cut back on research spending.

With the policy of budgetary restraint being followed by the present government, the problem is worsening. Professor Andre Jaumott, ex-chancellor of the Universite Libre de Bruxelles, wants universities to separate their teaching and research functions, with no budget restrictions.

Maystadt has other plans. His ministry has asked Belgian industry and the state
New broom in Spain

\section{Barcelona}

Professor Federico Mayor Zaragoza, the new Spanish Minister of Education and Science, is assessing the draft of a law for scientific and technical research which should provide a framework for scientific research in Spain, something that has been almost untouched since General Franco's time.

Professor Mayor is well versed in the higher education and science politics of Spain, having occupied many key posts: rector of the University of Granada, acting president of CSIC (the Spanish science research council), president of the "Comisión Asesora" (the main fund for research grants) and "subsecretario" (vice-minister) of education and science. He is now professor of biochemistry at the Autonomous University of Madrid and director of the Institute of Molecular Biology which is a unit of the "Centro de Biología Molecular Severo Ochoa". He was elected MP for Granada in 1979, but later resigned to become deputy director-general of UNESCO.

According to the draft law, the government intends to specify who will formulate Spanish science policy, who will control the different levels of organization and how research will be financed. It puts research under the control of a secretary of state who will report directly to the prime minister. An advisory committee, mainly composed of scientists, will propose general plans and priorities and submit an annual budget for research to parliament.

No change will be introduced in the structure of research bodies such as CSIC but, to circumvent the fact that these bodies have only permanent staff, a new institution will be created, which will be a public company that will employ research staff and act as an auxiliary to research centres. This will also facilitate the exchange of scientists between research institutes and universities. The draft will be offered for discussion to research institutions before going to parliament. However, new elections will take place before March 1983 and it is unlikely that such a complex law would pass through parliament before then.

Pedro Puigdoménech

departments what their research requirements are for the coming five years. On the basis of this information, research contracts are being handed out mainly to medium-sized companies to undertake this sort of applied research. For 1980-82, BFr 1,000 million ( $£ 11$ million) has been allocated on projects such as optic fibre technology for the Belgian PTT. Solvay, the Belgian chemical giant, should also benefit from funding for industry-orientated biotechnology.

\section{Martial law in Poland Fresh appeal}

A former president of the Polish Academy of Sciences, Dr Janusz Groszkowski, has sharply criticized a group of more than 140 intellectuals and academics who last month sent to the Sejm (parliament) an appeal for the ending of martial law.

The letter, which was also addressed to the United Nations General Assembly and the UN Commission on Human Rights, said that the imposition of martial law was contrary to the right of every nation to selfdetermination, and the freedom to determine its own political status and to ensure its economic, social and cultural development. This principle, it said, was the basis of the renewal movement which sprang up in Poland after August 1980. The letter particularly deplored "the attempts to divide the nation, setting workers against soldiers and the militia, the blockade of the means of communication in the whole country, the brutal breaking of workers' strikes by the militia and army, the internment of many thousands of people in prisons and camps. Cultural life, education and learning, it said, are being "paralysed", and the media rendered powerless.

Dr Groszkowski did not disagree with the content of the letter, nor with the demand that the authorities should "put an end to this confrontation with their own people". He felt, however, that the fact that such a letter was sent to the Sejm - a body which during the Gierek regime had totally lost the confidence of the Polish nation and indeed of the Communist party - did not give legitimacy to it. The Sejm, in its present form, is a creation of the Gierek period, now being exposed as an era of distortions and corruption. To approach an institution where people linked to the Gierek era are still active, was, he felt, "a serious political error".

Dr Groszkowski's letter reveals how little the reforms of the past 18 months have affected those in high places. In September 1980, a letter from $\mathrm{Dr}$ Groszkowski prompted the academy to call for major reforms in Polish political and academic circles from the Sejm downwards, to clean up political patronage and restore honesty and fair dealing to public life. Any appeal from $\mathrm{Dr}$ Groszkowski carries considerable weight among Polish academics - in 1976 he resigned as president of the academy when he was unable to gain legal redress for Mrs Aleksandra Hankus of the Krakow Technical University. Mrs Hankus had suffered 11 years of official harassment and almost a year in prison for libel after protesting, in 1964, that her research results had been stolen by a person enjoying political patronage who then went on to gain a doctorate on the strength of her work.

Vera Rich 